\title{
Entrevista com Francis Henrik Aubert
}

Guilherme da Silva Braga

Esta entrevista foi concedida pelo professor Francis Henrik. Aubert em São Paulo no dia 6 de setembro de 2018. John Milton e Telma Franco acompanharam-no em casa e auxiliaram-no com os aspectos técnicos, enquanto Guilherme da Silva Braga conduziu e gravou a conversa por videoconferência. Mais tarde o material gravado foi transcrito e adaptado, dando origem ao texto que segue. Em função de certas dificuldades para se expressar resultantes do AVC que o acometeu tempos antes da entrevista, o professor Francis Henrik Aubert teve as respostas editadas de maneira a resultar em um texto de leitura fluida. Esse texto foi disponibilizado ao entrevistado, que teve a oportunidade de lê-lo e oferecer sugestões e correções incorporadas nessa versão final da entrevista.

Guilherme da Silva Braga: Francis, como brasileiro e norueguês, tradutor literário, tradutor juramentado, professor de tradução da USP e autor de material teórico sobre tradução, você é praticamente o entrevistado ideal para esse número dos Cadernos de Literatura em Tradução. Como você resume essa trajetória com tantos papéis desempenhados nesse limite entre Brasil e Noruega, ou mais amplamente entre o Brasil e os países nórdicos?

Francis Henrik Aubert: Eu comecei a lecionar em 1968, na Noruega e a seguir na França. Minhas preocupações iniciais não eram com a tradução, mas com a relação entre significado e significante no âmbito da linguística teórica e da prática da tradução. Mas um pouquinho antes de 1979 eu fiz uma transição definitiva da linguística para a tradução. Foi nessa época que comecei a trabalhar com a tradução nas mais variadas modalidades. Quanto à minha trajetória pessoal, passei meus seis primeiros meses de vida no Brasil, como primeiro brasileiro da minha família. Dos seis meses aos meus quatro anos e meio eu morei na Noruega, depois voltei para 
o Brasil. Mas a cada dois ou três anos eu passava dois ou três meses na Noruega. Já adulto, passei cinco anos completando a minha graduação em Oslo, onde me casei. A seguir, passei um período de cerca de um ano e meio no Brasil e morei com a minha então esposa por dois anos e meio na França. E no fim voltei mais uma vez para o Brasil, onde permaneci.

GSB: Você ofereceu cursos de lingua e cultura norueguesa na USP. Como foi organizar esse tipo de formação em um país tão culturalmente distante como o Brasil?

FHA: Esses foram cursos à parte, oferecidos como disciplinas optativas para alunos da graduação. A ideia inicial era que o projeto durasse um semestre, mas aos poucos surgiram planos para um segundo. Infelizmente, enquanto eu preparava o segundo semestre eu caí doente e quase passei dessa para melhor. Assim só o primeiro semestre acabou se concretizando.

GSB: Em todo o material teórico que você produz̨iu sobre tradução, é sempre muito evidente a preocupação com o fato de que a tradução não é uma operação que se dá entre palavras on entre línguas, mas no plano da cultura subjacente às linguas. No caso de culturas tão distantes como a cultura brasileira e a cultura norueguesa, que tipo de reflexos esse tipo de atenção traz. para a prática da tradução?

FHA: Trabalhar com essas culturas é uma situação muito boa. Excepcional, mas também muito boa. Em meados dos anos 80 eu pude ir além das culturas mais tradicionais que todo mundo conhece e passei a trabalhar com o norueguês, que se tornou um aspecto importante do meu trabalho por cerca de vinte anos, envolvendo-me inclusive com modalidades de tradução que considero realmente especiais, como a tradução juramentada norueguês-português e português-norueguês.

GSB: Houve uma época em que a literatura foi tratada como uma modalidade especial de tradução, porém em tempos mais recentes surgiram teorias mais generalistas que se propõem a descrever todo e qualquer tipo de tradução possivel. Como você percebe essa relação entre a tradução literária e a tradução de textos não literários?

FHA: Para mim, a tradução juramentada e a tradução literária são casos especiais que estão nos dois extremos de tudo aquilo que se poderia considerar ramerrão ou 
“normal” em tradução. É uma questão de ponto de vista, mas no limite parece-me possível empregar uma teoria única com segmentações internas adequadas que deem conta dessas diferentes modalidades.

GSB: No plano literário, você traduz̨iu diversas peças de Ibsen, contos de Asbjornsen e Moe e o romance contemporâneo Halvbroren, de Lars Saabye Christensen [publicado no Brasil como $\mathrm{O}$ meio irmão]. Morando no Brasil, que tipo de contato você mantém com a literatura da Noruega? Com que obras da literatura norueguesa você ainda gostaria de se envolver como tradutor?

FHA: Teve uma coisa que eu infelizmente não consegui fazer na época em que fui vice-diretor e então diretor da Universidade, que foi me dedicar à tradução literária com afinco. $\mathrm{O}$ resultado foi que, quando pude retornar à atividade como tradutor literário, o livro que eu gostaria de traduzir já tinha sido traduzido por um amigo meu, João Azenha, a partir do alemão. Esse livro era Sofies verden [publicado no Brasil como $O$ mundo de Sofia], que mais tarde foi retraduzido diretamente do norueguês [por Leonardo Pinto Silva]. Agora eu vou aos poucos retomando a tradução literária: estou em um ponto bom para recomeçar. Já que vou continuar por aqui durante mais algum tempo - por uns vinte anos antes de ir dessa para melhor, digamos assim - ainda consigo preparar uns livros do dano-norueguês dos séculos XVIII, XIX e XX, de autores como Ludvig Holberg, Bjornstjerne Bjornson, Henrik Ibsen e Odd Eidem.

GSB: Qual foi a lingua que você primeiro aprendeu a falar?

FHA: Eu cresci falando primeiro norueguês, por causa do meu pai, e depois inglês, por causa da minha mãe. Quando eu tinha por volta de quatro anos e meio e voltei para o Brasil, comecei a perceber também o português, e assim com seis anos eu era trilíngue. A literatura norueguesa trouxe as primeiras histórias que foram lidas para mim, e mais tarde comecei a me interessar pela literatura brasileira de Padre Vieira, Machado de Assis, Monteiro Lobato... na minha adolescência eu passei a me comunicar principalmente em português e inglês, e assim o meu norueguês acabou ficando meio de lado. Só retomei a língua quando retornei à Noruega para cursar a minha graduação. 
GSB: Em 1974 você retornou ao Brasil e aqui se fixou em caráter definitivo. Como você fez. para manter o contato com a sua lingua paterna por aqui, onde as oportunidades para falar e estudar essa língua são tão poucas?

FHA: Eu contava com a minha ex-mulher e os três filhos do meu primeiro casamento, que permaneceram morando na Noruega, para me enviar livros.

GSB: De uns anos para cá, a literatura nórdica como um todo, impulsionada pela literatura policial, passou a ter bastante espaço no panorama literário do Brasil. Como uma pessoa de perspectiva bastante privilegiada em relação à cultura brasileira e à cultura norueguesa, o que você acredita que ambas tenham de interessante uma para a outra?

FHA: São culturas muito diferentes. A Suécia, a Noruega e a Dinamarca têm uma história cultural muito próxima, e ao mesmo tempo muito diferente da cultura de outros países. E os países nórdicos, embora pequenos, produzem uma grande quantidade de literatura em relação à população que têm. Uma parcela significativa de pessoas em algum momento da vida escreve um livro. E há também uma igualdade social muito grande.

GSB: Anos atrás você sofreu um AVC que o deixou em situação bastante grave e provocon um problema de afasia, um distúrbio neurológico que afeta diretamente a linguagem e a capacidade de falar. Como um homem que passou uma vida inteira trabalhando com linguas e prestando atenção em como se fala e o que se diæ, como foi essa experiência de perder a capacidade da linguagem e aos poucos recuperá-la?

FHA: Foi uma jornada e tanto, e continua sendo uma coisa meio complicada para mim, que ainda não está perfeita. Eu preciso me exercitar todos os dias para tentar aos poucos reconstruir o que perdi. E ainda há muito para ser feito, não tenho dúvida nenhuma. O português, o inglês e o norueguês já estão mais ou menos estáveis. $\mathrm{O}$ francês ainda está com alguns problemas, mas aos poucos vai melhorando.

GSB: No meio disso tudo foi inaugurado um laboratório de tradução com o seu nome na USP. Que atividades devem funcionar nesse laboratório e qual é o seu envolvimento com esse projeto? 
FHA: Eu gostaria de fazer com que as pessoas tivessem uma atitude positiva em relação à tradução, que percebessem a tradução como uma atividade boa de se fazer. Estou muito entusiasmado com o projeto e pretendo oferecer aulas e oficinas e dar continuidade ao curso de língua e cultura norueguesa. Mesmo sendo agora aposentado eu pretendo render ainda uns vinte anos, se Deus quiser. 